(C) 2018

\title{
Strategies of innovative development of forage industry of Ukraine in conditions of today's calls
}

\author{
Petrychenko V., Korniichuk O., \\ Academician of NAAS, Doctor of Agricultural Sciences \\ O.V. Korniichuk, \\ Candidate of Agricultural Sciences \\ Institute of Feeds and Agriculture of Podillia of NAAS
}

The purpose. To study conceptual approaches to the strategy of innovative development of forage industry of Ukraine in conditions of becoming of world agroindustrial production. Methods. Systems analysis, analytical, mathematical-and-statistical, monographic, calculative-relative. Results. Conceptual approaches to the strategy of development of forage industry which are based on transfer of innovations into the branch are offered. Conclusions. Transfer of innovations into forage industry will promote revitalization of competitive animal husbandry, formation of food safety of the state in conditions of climate fluctuation and further development of euro integration processes.

Statement of the problem. Active growth of demand for livestock products in the countries, where economy is developing most dynamically, has caused a large-scale increase in its production. This has been accompanied by significant technological innovations and structural changes in agrarian production. It is known that nutritional needs of the population are met due to the development of industrial livestock production and related food chains. At the same time, millions of rural residents continue to keep animals within the limits of traditional production systems that helps to ensure livelihoods and food security of the state, which to a large extent is inherent in the modern Ukrainian village.

Analysis of recent research and publications. Today, many researchers pay attention to urgent issues of the technology of production and use of feeds, their classification by the origin, nutritional value and significance, nomenclature, identification, and biochemical state. Special attention is paid to the nature of nutrients and biologically active substances in numerous fundamental works of domestic scientists in the field of feed production, feeding of farm animals and poultry $[0,0]$. The problems of practical production and use of feed protein for farm animals are examined in the papers of foreign scientists [0-0].

The purpose of this study is to highlight the conceptual approaches to the strategy of innovation development of Ukraine's feed production under current conditions of formation of the world agro-industrial production.

Research results. The strategy of the agrarian sector development in the Ukrainian economy by 2025 emphasizes the growing role of scientific support of innovative development, formation of partnership relations between modern agribusiness, the state and branch science in the field of seed production development, breeding and pedigree stock-breeding, technical and technological support of the agrarian sector [ 8]. In particular, in 2025, it is forecasted to produce 16.1 million tons of milk, 3.9 million tons of meat in slaughter mass and 20.9 billion eggs, which will contribute to the food security of Ukraine. It is expected that 1 ton of high quality feed should provide production of 1 ton of milk, 0.13 tons of cattle meat, 0.3 tons of pig meat, 0.45 tons of poultry meat, and 5.5 thousand eggs. Only under such conditions, strategy implementation will enable to develop organizational and economic basis for efficient, socially oriented development of the agrarian sector of economy, stable industry supply with agricultural raw materials, and the population with high-quality and safe domestic agricultural products. An increase in the volume of production with high added value will ensure Ukraine's presence in the world market of agricultural products and food. 
There is another project -Agribusiness Development Strategy " $3+5$ ", which has three basic priorities, namely, a reform of the state support system with an emphasis on small farmers, completion of the land reform and the reform of state enterprises. It also has five key directions, i.e. the development of sales markets, production of organic and niche crops, rural development, irrigation, and food safety [0].

However, these strategies do not take into account the dynamics of the livestock sector development, the trends that have taken place in recent years, the challenges associated with climate change and European integration processes. In this article, we have tried to assess objectively the state of forage and livestock production and to outline approaches of innovative development.

The analysis of livestock sector development in Ukraine shows that over the years there has been a decline in livestock and milk production both in the households that produce more than $75 \%$ and in the public sector (Table 1).

Table 1. Evaluation of the state of livestock production development in Ukraine

\begin{tabular}{|c|c|c|c|c|c|c|}
\hline \multirow{2}{*}{ Indicators } & \multicolumn{6}{|c|}{ Years } \\
\hline & 1990 & 2000 & 2005 & 2010 & 2015 & 2016 \\
\hline \multicolumn{7}{|c|}{ Livestock number at the end of the year, mln heads: } \\
\hline Cattle, total & 24,6 & 9,4 & 6,5 & 4,5 & 3,9 & 3,7 \\
\hline including cows & 8 & 5 & 4 & 2,6 & 2,3 & 2,1 \\
\hline Pigs & 19,4 & 7,7 & 7,1 & 8,0 & 7,4 & 6,7 \\
\hline Sheep and goats & 8,4 & 1,9 & 1,6 & 1,7 & $\overline{1,4}$ & 1,3 \\
\hline Poultry & 246 & 124 & 162 & 203,8 & 213,3 & 202,4 \\
\hline \multicolumn{7}{|c|}{ Production } \\
\hline $\begin{array}{l}\text { Meat production } \\
\text { (in live weight), } \mathrm{mln} t\end{array}$ & 6,5 & 2,3 & 2,4 & 2,9 & 3,2 & 3,3 \\
\hline Milk production, $\mathrm{mln} \mathrm{t}$ & 24,5 & 12,7 & 13,7 & 11 & 11 & 10 \\
\hline Egg production, billion eggs & 16,3 & 8,8 & 13,0 & 17,1 & 16,8 & 15,1 \\
\hline \multicolumn{7}{|c|}{ Livestock productivity } \\
\hline Average daily gain of cattle & 431 & 255 & 392 & 461 & 536 & 539 \\
\hline Average daily gain of pigs & 229 & 120 & 281 & 375 & 487 & 493 \\
\hline Average annual milk yield per cow, kg & 2863 & 2359 & 3482 & 3975 & 5438 & 5658 \\
\hline $\begin{array}{l}\text { Average annual eggs laying capacity per } \\
\text { chicken, egg }\end{array}$ & 214 & 213 & 274 & 281 & 263 & 252 \\
\hline
\end{tabular}

Such dependencies are the result of a complex effect of important socio-economic factors. However, ineffective technologies of farm animal keeping and feeding play an important role here. Over the period of 2010-2016, the total cattle population decreased by $23 \%$ ( 3.7 million heads), including cows by $22 \%$ ( 2.1 million heads), pigs by $16 \%$ (6, 7 million heads), sheep and goats by $28 \%$ ( 1.3 million heads).

Growth of poultry number (214 million heads) had been observed by 2014, while at the beginning of 2017 it amounted to 202 million goals. Production of the main types of products - milk by $7 \%$, eggs by $12 \%$ - is also decreasing. $76 \%$ of milk production and $40 \%$ of meat of all kinds are concentrated in the households. Therefore, we believe that it is necessary to change the structure of milk and meat production in the state in favor of organized small and large-scale agroformations. Such formations have an opportunity to carry out technical and technological modernization and ensure scientific basis of the breeding and genetic work, sanitary and veterinary support, quality control and safety of livestock products and feed.

By the level of milk and meat consumption, Ukraine is considerably inferior to developed countries, therefore, domestic producers are interested in the increase of food and feed grain and oilseed crops production volumes, as the demand for food, feed and bio-resources is growing. 
In recent years, the volumes of feed production have remained almost unchanged, and they are characterized by a slight reduction in the areas under forage crops and an increase in their production. The share of forage crops in the total cropping area is $7.2 \%$ and amounts to 1.9 million ha (Fig. 1).

In the structure of areas under forage crops, perennial grasses occupy $52 \%$, annuals - about $20 \%$, corn for silage $-15 \%$. Therefore, it is particularly important to ensure sustainable development of feed production and increase productivity of arable land under fodder crops as one of pre-conditions for a competitive modern livestock production.

In solving this issue, the leading position will belong to innovative high-end technologies that will ensure implementation of the strategy of maximizing yield capacity of grain and oilseed crops, preserving the environment, reducing greenhouse gas emissions, and promoting sustainable development of rural areas.

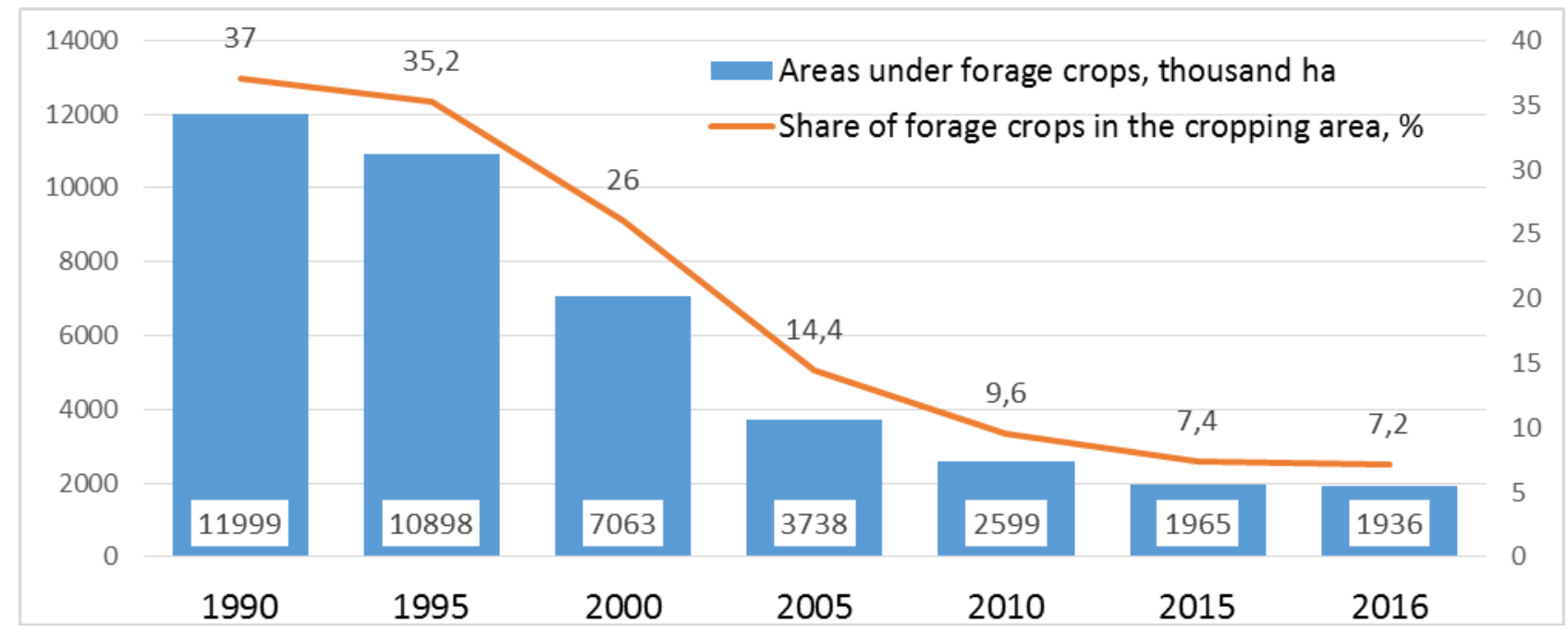

Fig. 1. Dynamics of the areas under forage crops and their share in the total cropping area of Ukraine

In the coming years, the state's innovation and investment policy and timely response to the world trends in the production of grain and oilseed crops as well as completion of the land reform, which will determine the development of agricultural production for a long period of time, are becoming of great importance for Ukraine.

According to the experience of the leading countries of the world, approaches to sustainable development of agro-ecosystems are the basis of modern agricultural production. A vivid example of successful implementation of these approaches is the American agrarian model of development. Its viability is proved by the fact that the crisis in 2008 did not significantly affect agricultural production. Thus, in 2007 and 2010 , the same grain yield was harvested in the USA - 416 million tons each year. This was achieved, first of all, due to the regional specialization and concentration, which ensure distribution of crops considering bioclimatic potential, exports, needs of the domestic market and logistics. As a result, in the "Corn Belt", which includes only five states, nearly 210 million tons of corn or $63 \%$ of corn grown in the country are produced. A similar dependence is observed in the production of wheat food grain in the "Wheat Belt" - 31 million tons of grain or $52 \%$ of the total volume [0].

The same theoretical provisions for the sustainable grain production are the basis of the agrarian policy in the leading EU countries, in particular France and Germany. In particular, in 2009, grain production in France exceeded 70 million tons with a grain yield of 7.4 tons per hectare on the area of 9.4 million hectares and in Germany, respectively, 49.7 million tons with a grain yield of 7.2 tons per hectare on the area of 6.9 million hectares. Therefore, France is one of the largest exporters of wheat, corn and barley grain leaving Ukraine behind. Germany is one of the largest importers of livestock products in the EU, while the needs for feed protein are met due to imports of 3.5 million tons of soybean and 300,000 tons of soybean meal per year [0].

At the same time, feed producers of industrial livestock countries are trying to reduce grain share to 40$45 \%$ due to the introduction of protein components, by-products of the food and processing industries. 
Protein balance is one of the main factors of sustainable development and formation of the forage base. Thus, in the grain structure of the US, wheat accounts for about 60 million tons, soybean - 91 million tons, and corn - 333 million tons [10]. The growth of soybean production and use has become the basis of agriculture intensification in many countries of the world, and the most highly developed countries are the main consumers of soybean meal. In particular, China -48 million tons, the EU -33.3 million tons, the USA -28 million tons, Brazil - 14 million tons [0].

Advanced experience of the leading countries indicates that the diets of cows should be oriented towards beneficial effects of feeds and maximum use of the physiological potential of animals to achieve effective results in dairy cattle breeding (Table 2 ).

Regeneration of livestock production may become one of the stabilizing factors of the intensification of grain and protein-oil crop production, since it will always be its constant consumer. It will also contribute to the intensification of forage crop cultivation, mainly perennial legume grasses, which will become an additional factor of crop rotation significance for sustainable development of agroecosystems. Since a substantial increase in the number of cows at the industrial enterprises is impossible due to their individual reproduction, the main reserve of milk production increase is the enhancement of animal productivity.

Table 2. Conceptual approaches to effective feeding rationing in the dairy cattle breeding

\begin{tabular}{|c|c|c|}
\hline Annual milk yield & $7000-8000 \mathrm{~kg} / \mathrm{head}$ & $10000-12000 \mathrm{~kg} / \mathrm{head}$ \\
\hline $\begin{array}{l}\text { Share of concentrates in } \\
\text { the diet }\end{array}$ & up to $30 \%$ & over $45 \%$ \\
\hline Milk yield from bulky feeds & $60 \%$ & $40 \%$ \\
\hline Number of lactations & $5-6$ & up to 4 \\
\hline Feed costs & $50 \%$ & $50 \%$ \\
\hline Veterinary costs & $1,5-2,0 \%$ & $3,5-4,0 \%$ \\
\hline $\begin{array}{l}\text { Expenses for pedigree } \\
\text { work }\end{array}$ & up to $0,4 \%$ & $1,5-2,0 \%$ \\
\hline Management & $\begin{array}{l}\text { The use of traditional approaches } \\
\text { to livestock feeding and } \\
\text { maintaining based on rationing }\end{array}$ & $\begin{array}{l}\text { Diets are oriented to coefficient of feed } \\
\text { efficiency. Maximum use of pastures, } \\
\text { canned forage and bulky feeds to } \\
\text { promote healthy function of the paunch. } \\
\text { Implementation of preventive measures } \\
\text { to prevent livestock morbidity. } \\
\text { Development of pedigree stock- } \\
\text { breeding. }\end{array}$ \\
\hline Production without losses & $\begin{array}{l}\text { Production without losses under } \\
\text { purchasing prices from } 19 \\
\text { eurocent }\end{array}$ & $\begin{array}{l}\text { Production without losses under } \\
\text { purchasing prices from } 25 \text { eurocents }\end{array}$ \\
\hline
\end{tabular}

Solution of this problem requires implementation of a number of measures aimed to introduce advanced livestock production technologies and increase the level of implementation of the genetic potential of animal productivity, which is currently lower than $60 \%$. Production of mixed feeds and soybean meal meets the needs only by $40-50 \%$. It is positive that production and use of meal for forage purposes has increased by $44 \%$ (Table 3).

In 2016, 6.3 million tons of barley was produced, among which 1.3 million tons was consumed for feed purposes, including $69 \%$ of sunflower and $31 \%$ of soybean meal, and more than 5 million tons was exported. Production of corn for grain increased 2.3 times, while domestic consumption increased only by $30 \%$ and exports increased 3.6 times. At the same time, indicators of the feed nutritional value have a low conversion - for the production of cattle growth -11.93 feed units, pig growth -6.28 feed units, which is $28-30 \%$ lower 
than rationally justified norms in normalized feeding. Sometimes vegetable forages having a low level of digestible protein content (90-100 g per 1 feed unit) are used. While milk production meets the established requirements -0.97 feed units.

At the current stage of development of economic relations, diversification of production and agrarian market is taking place. The shortage of feeds, forage protein, low animal productivity lead to the search for alternative, cost-effective options for the organization of feed production on the basis of the market economy - formation of the feed market. It is traditionally believed that the feed market is represented by the products of feed industry, but nowadays livestock producers need to feed more and more animal protein in the form of plant concentrates and non-food ingredients. For this reason, it is very important for Ukraine to form its feed market and obtain a positive economic effect from the maintenance of farm animals, and for the society - to ensure food security.

Table 3. Production and consumption of concentrated feeds in Ukraine, thousand tons

\begin{tabular}{|l|c|c|c|c|c|c|c|c|}
\hline \multirow{2}{*}{ Indicators } & \multicolumn{7}{c|}{ Years } \\
\cline { 2 - 8 } & 2010 & 2011 & 2012 & 2013 & 2014 & 2015 & 2016 \\
\hline Production & 442 & 537 & 466 & 593 & 695 & 711 & 750 \\
\hline Export & 5 & 5 & 15 & 80 & 216 & 347 & 350 \\
\hline Import & 40 & 25 & 7 & 3 & 2 & 2 & 2 \\
\hline $\begin{array}{l}\text { Domestic } \\
\text { consumption }\end{array}$ & 465 & 589 & 430 & 480 & 460 & 420 & 400 \\
\hline \multicolumn{7}{|c|}{ Sunflower meal } \\
\hline Production & 3296 & 3930 & 3599 & 4703 & 4223 & 4797 & 5392 \\
\hline Export & 2927 & 3837 & 3052 & 3648 & 3394 & 3817 & 4700 \\
\hline Import & 1 & 1 & 2 & - & 6 & 1 & - \\
\hline $\begin{array}{l}\text { Domestic } \\
\text { consumption }\end{array}$ & 370 & 220 & 540 & 680 & 750 & 850 & 900 \\
\hline \multicolumn{7}{|c|}{ Corn for grain } \\
\hline Production & 11919 & 22838 & 20961 & 30950 & 28497 & 23328 & 27600 \\
\hline Export & 5008 & 15208 & 12726 & 20004 & 19661 & 16595 & 18000 \\
\hline Import & 38 & 49 & 44 & 66 & 28 & 28 & 50 \\
\hline $\begin{array}{l}\text { Domestic } \\
\text { consumption }\end{array}$ & 6500 & 7800 & 8100 & 9700 & 9400 & 8000 & 8300 \\
\hline $\begin{array}{l}\text { Including for } \\
\text { purposes }\end{array}$ & 5400 & 6500 & 6800 & 8300 & 8000 & 6700 & 6900 \\
\hline
\end{tabular}

Feed costs account for more than half of all costs in livestock production, which makes the process of the feed base formation an important aspect of the activity of all agrarian commodity producers. According to the results of analytical studies on the cost structure of the main types of livestock products, it has been found that the share of the feed cost is increasing year by year (Table 4).

Table 4. Share of feeds in the cost of livestock products in Ukraine, \%

\begin{tabular}{|c|c|c|c|c|c|c|c|c|}
\hline \multirow{2}{*}{ Years } & \multicolumn{5}{|c|}{ Growing for meat } & \multirow{2}{*}{ Milk } & \multirow{2}{*}{ Wool } & \multirow{2}{*}{$\begin{array}{c}\text { Chicken } \\
\text { eggs }\end{array}$} \\
\hline & cattle & pigs & sheep & goats & poultry & & & \\
\hline 2010 & 54,2 & 63,6 & 44,3 & 50,4 & 63,8 & 47,0 & 38,7 & 63,7 \\
\hline 2011 & 55,2 & 65,4 & 43,8 & 44,4 & 69,6 & 47,6 & 36,5 & 68,1 \\
\hline 2012 & 55,2 & 65,7 & 46,7 & 36,7 & 68,7 & 48,4 & 37,7 & 58,9 \\
\hline 2013 & 56,0 & 67,0 & 48,8 & 56,2 & 67,5 & 49,9 & 40,1 & 60,4 \\
\hline
\end{tabular}




\begin{tabular}{|c|c|c|c|c|c|c|c|c|}
\hline 2014 & 56,0 & 67,2 & 51,7 & 50,6 & 67,8 & 47,9 & 44,4 & 63,6 \\
\hline 2015 & 56,4 & 69,7 & 54,3 & 50,7 & 72,2 & 51,5 & 47,5 & 75,1 \\
\hline 2016 & 59,1 & 70,1 & 51,4 & 38,1 & 70,8 & 54,6 & 41,9 & 68,3 \\
\hline Change, \pm & $+4,9$ & $+6,5$ & $+7,1$ & $-12,3$ & $+7,0$ & $+7,6$ & $+3,2$ & $+4,6$ \\
\hline
\end{tabular}

A more detailed analysis of milk production costs at the agricultural enterprises in Ukraine has shown that the productivity of cows increases when feed rations are optimized, where production costs per cow with the productivity of more than $6000 \mathrm{~kg}$ of milk make up more than 20 thousand UAH per year.

When milk production was investigated at some agricultural enterprises of Vinnytsia region, which in 2016 hold the leading position in milk production in Ukraine, it was established that the share of the feed cost in the prime cost of milk was the lowest under percentage correlation of concentrated, succulent, coarse and other feeds by their nutritional value $44: 34: 19: 3$ (table 5).

The highest productivity of cows was achieved at the farms, where concentrated feeds occupied $40-50 \%$ in the diets of cows. The highest level of marginal income (over 300 UAH per 1 centner of milk) was obtained at the farms with the productivity of more than $7000 \mathrm{~kg}$ and under the diet structure of 44: 36: 15: 5. The maximum limit of concentration of concentrated feeds is $40-45 \%$, succulent $-30-35 \%$, coarse $-15-20 \%$ and others about $5 \%$ in terms of nutritional value.

Table 5. Grouping of costs by the level of milk productivity of cows, 2016

\begin{tabular}{|l|c|c|c|c|c|}
\hline \multicolumn{1}{|c|}{ Production costs, UAH/head } & $\begin{array}{c}\text { up to } \\
10000\end{array}$ & $\begin{array}{c}10001- \\
15000\end{array}$ & $\begin{array}{c}15001- \\
20000\end{array}$ & $\begin{array}{c}\text { over } \\
20000\end{array}$ & In Ukraine \\
\hline Number of livestock, thousand animals & 10 & 110 & 159 & 226 & 505 \\
\hline Milk produced, thousand tons & 30 & 447 & 816 & 1376 & 2669 \\
\hline Milk yield per cow, kg & 3096 & 4071 & 5133 & 6069 & 5438 \\
\hline Production costs per head, UAH & 7996 & 12634 & 16297 & 22529 & 18279 \\
\hline Share of feeds in the structure of milk cost, \% & 53 & 51,8 & 51,6 & 51,4 & 51,5 \\
\hline concentrated & 34,7 & 34,8 & 37,2 & 44,6 & 40,4 \\
\hline succulent & 22,6 & 29,1 & 37,6 & 33,8 & 33,9 \\
\hline coarse & 26,4 & 23,2 & 20,3 & 18,7 & 20,1 \\
\hline others & 16,3 & 12,9 & 4,9 & 2,9 & 5,6 \\
\hline
\end{tabular}

Full value of feeding at the agricultural enterprises depends on the stability of the forage base, efficiency of livestock supply with high-quality feeds. Intensive technologies for forage harvesting in large-scale agroformations enable to introduce typical livestock feeding with full-value feed mixtures enriched with feed additives, and, thus, guarantee farms technological and economic advantages in production.

\section{Conclusions}

The main conceptual approaches to the strategy of modern feed production development are the introduction of high-end innovative technologies of cultivation, harvesting, storage and use of feeds, which will become the basis for the revival of competitive livestock production and ensure food security of the state. Besides, innovative feed production is to ensure sustainable functioning of agro- ecosystems.

\section{Bibliography}

1. Petrychenko V.F., Korniichuk O.V., Babych A.O. et al. (2014) The concept of feed production development of Ukraine up to 2025. Podillya Institute of Forage and Agriculture NAAS. $-12 \mathrm{p}$.

2. Petrychenko V.F., Korniichuk O.V. (2012). Strategy of feed production development in Ukraine. Feeds and Feed Production. 2012. № 73. P. 3-10.

3. Protein Sources for the Animal Feed Industry. Food And Agriculture Organization of the United Nations Rome, 2004. 25 p. 
4. Gale F. (2015). Development of China's Feed Industry and Demand for Imported Commodities / Fred Gale // A Report from the Economic Research Service. - November 2015. - 26 p.

5. Vandoni S. (2017). Protein feeding: the golden middle. Milk and farm.- № 2 (39). - P. 100-107.

6. Salmon D.G., Lefebvre L. (2014). French Plan for Protein Crops 2014-2020. Global Agricultural Information Network (GAIN). Paris. December 2014. - 4 p.

7. Global Medicinal Feed Additives Market 2016-2020. The world's largest market research store. Research and Markets. February, 2016. -84 p.

8. Gadzalo Y.M. (2016). The Draft Strategy for the Development of Agricultural Production in Ukraine for the period up to 2025. Kyiv: Agrarian Science. $213 p$.

9. Strategy of Agrarian Sector Development "3+5". Ministry of Agrarian Policy and Food of Ukraine. 2016. $16 \mathrm{p}$.

10. Agricultural Statistics 2016. National Agricultural Statistics Service. United States Government Printing Office Washington: 2016. $-510 \mathrm{p}$.

11. Agriculture, forestry and fishery statistics - 2016 edition. Luxembourg: Publications Office of the European Union, 2016. $-230 \mathrm{p}$.

12. Oilseeds: Worlds Markets and Trade. United States Department of Agriculture Foreign Agricultural Service Approved by the World Agricultural Outlook Board. USDA. - July 2017. - 38 p. 